BOT. GAZ. 145(3):395-406. 1984 .

(C) 1984 by The University of Chicago. All rights reserved.

0006-8071/84/4503-0007\$02.00

\title{
SECONDARY PHLOEM ANATOMY IN CALLISTOPHYTON BOYSSETII (RENAULT) ROTHWELL AND HISTOLOGICAL CHANGES IN THE OUTER PHLOEM
}

\author{
EDITH L. SMOOT ${ }^{1}$
}

Department of Botany, Ohio State University, Columbus, Ohio 43210

\begin{abstract}
Specimens with well-preserved phloem tissues of the pteridosperm Callistophyton boyssetii from coal balls in the Herrin no. 6 Coal of Illinois and the Bevier Coal of Kansas are described. The secondary phloem consists of alternating tangential bands of sieve cells and parenchyma, separated by vascular rays. Secretory cells are scattered throughout the secondary phloem, and bundles of presumed primary phloem are evenly distributed in the cortex. Histological differences between the inner (presumably functional) and the outer (presumably nonfunctional) phloem are described: changes in cell shape, thickening of cell walls, and deposition of dark-colored cell contents. In contrast to living plants, both parenchyma cells and conducting elements appear to undergo these changes. Phloem anatomy and developmental changes in the outer phloem in Callistophyton are compared with those in other Carboniferous seed ferns and extant gymnosperms.
\end{abstract}

\section{Introduction}

Callistophyton (DELEVORYAS and MORGAN 1954) is one of the most completely known Paleozoic seed ferns (ROTHWELL 1975, 1980). Recently placed in their own order (ROTHWELL 1981), the Callistophytales have many vegetative and reproductive features that set them apart from both the medullosan and the lyginopterid pteridosperms. Phloem has been observed in several specimens of Callistophyton (BERTRAND and RENAULT 1886), including the type material examined by DELEVORYAS and MORGAN (1954). In his study of Callistophyton, ROTHWELL (1975) noted features of the secondary phloem, including cellular composition of the tissue and primary phloem in young stems. BERTRAND and RENAULT (1886), BERTRAND (1889), DELEVORYAS and MORGAN (1954), and ROTHWELL (1975) illustrated sieve elements with well-preserved sieve areas on their radial walls.

The most extensive investigation of secondary phloem anatomy in Callistophyton to date was the work of RUSSIN (1981). Although he compared the phloem anatomy of Callistophyton with other fossil and living gymnosperms, he was unable to make a comparison with other Carboniferous pteridosperms since data were available only for stems of Heterangium (HALL 1952). ROTHWELL (1981) has suggested that the Callistophytales may represent a group with features that are intermediate between cordaite- or conifer-like plants, on the one hand, and other Paleozoic seed ferns, on the other. In light of this work, an examination of the structure and phylogenetic significance of Callistophyton phloem is needed, especially from a systematic viewpoint. A detailed comparison of phloem anatomy in the Callistophytales and the Medullosales (SMOOT 1984) may provide some additional data

\footnotetext{
1 Current address: Department of Biology, Hope College, Holland, Michigan 49423.

Manuscript received October 1983; revised manuscript received January 1984.
}

to evaluate the systematic position of these Carboniferous plants.

\section{Material and methods}

Axes of Callistophyton boyssetii (Renault) Rothwell were obtained from coal balls collected in the Mackie Clemens no. 23 mine, Crawford County, Kansas (Middle Pennsylvanian, Bevier Coal, Bevier Formation, Cherokee Group, Joplin Quad.-Sec. 21, T9S, R25E), and the Sahara locality in Williamson County, Illinois (Middle Pennsylvanian, Herrin no. 6 Coal, Carbondale Formation, Kewanee Group, Harrisburg 15' Quad.-Sec. 30, T9S R4E). See PHILLIPS (1980) for further stratigraphic details on coal ball sites in North America.

Material was prepared for light microscopy using the cellulose acetate peel technique (JOY et al. 1956; STEWART and TAYLOR 1965). Coal balls, slides, and peels of coal balls nos. 303 and 384 are deposited in the Paleobotanical Collection, Department of Biology, Western Illinois University, Macomb. Material from coal ball no. 2130 is deposited in the Paleobotanical Collection, Department of Biology, Emporia State University, Emporia, Kansas; and material from nos. 589, 929, $979,1966,2259,2296$, and 8010 is deposited in the Paleobotanical Collections, Department of Botany, Ohio State University, Columbus, under acquisition nos. 10,163-10,255, and 13,031-13,032.

\section{Observations}

\section{GENERAL ANATOMY}

All specimens represent stems of Callistophyton boyssetii and range from ca. 6 to $14.2 \mathrm{~cm}$ in diameter. Stems exhibit anatomical features typical of the genus, including parenchymatous pith containing scattered cells with dark contents, abundant secondary xylem, and primary cortex with secretory cavities (figs. 1, 2). In well-preserved specimens, phloem tissue is continuous with the vascular cambium on the inside and the cortex (or 

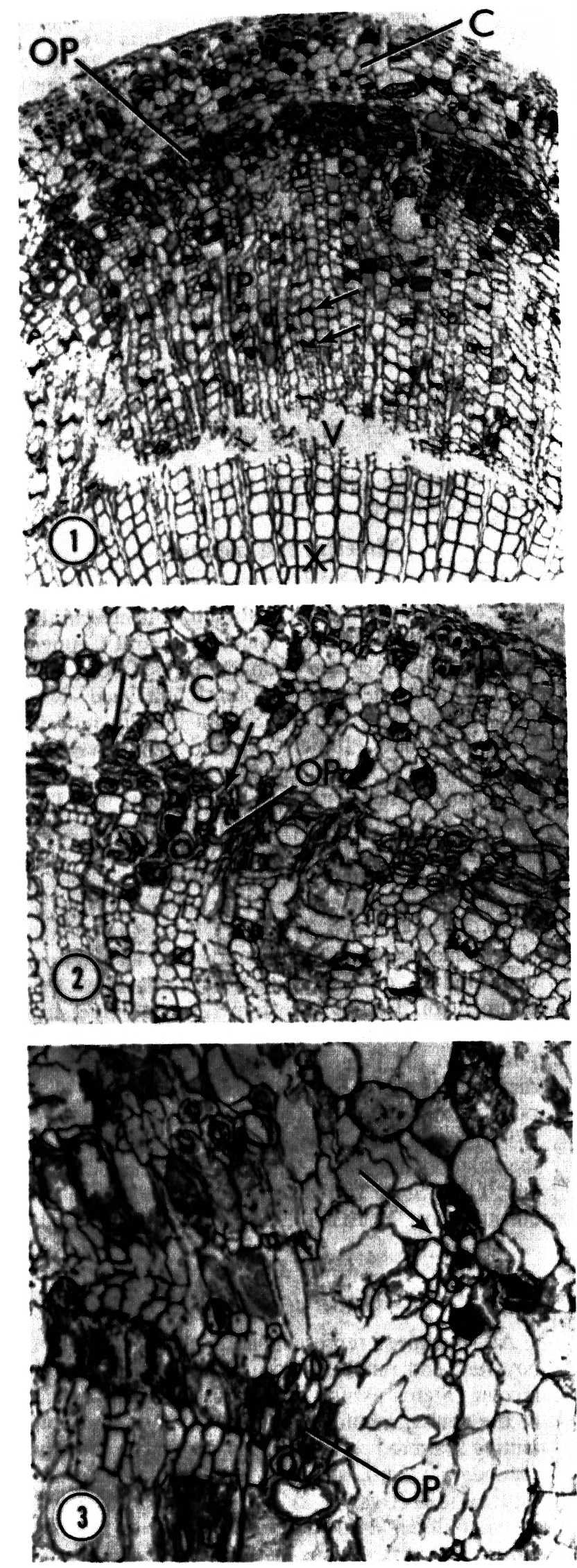
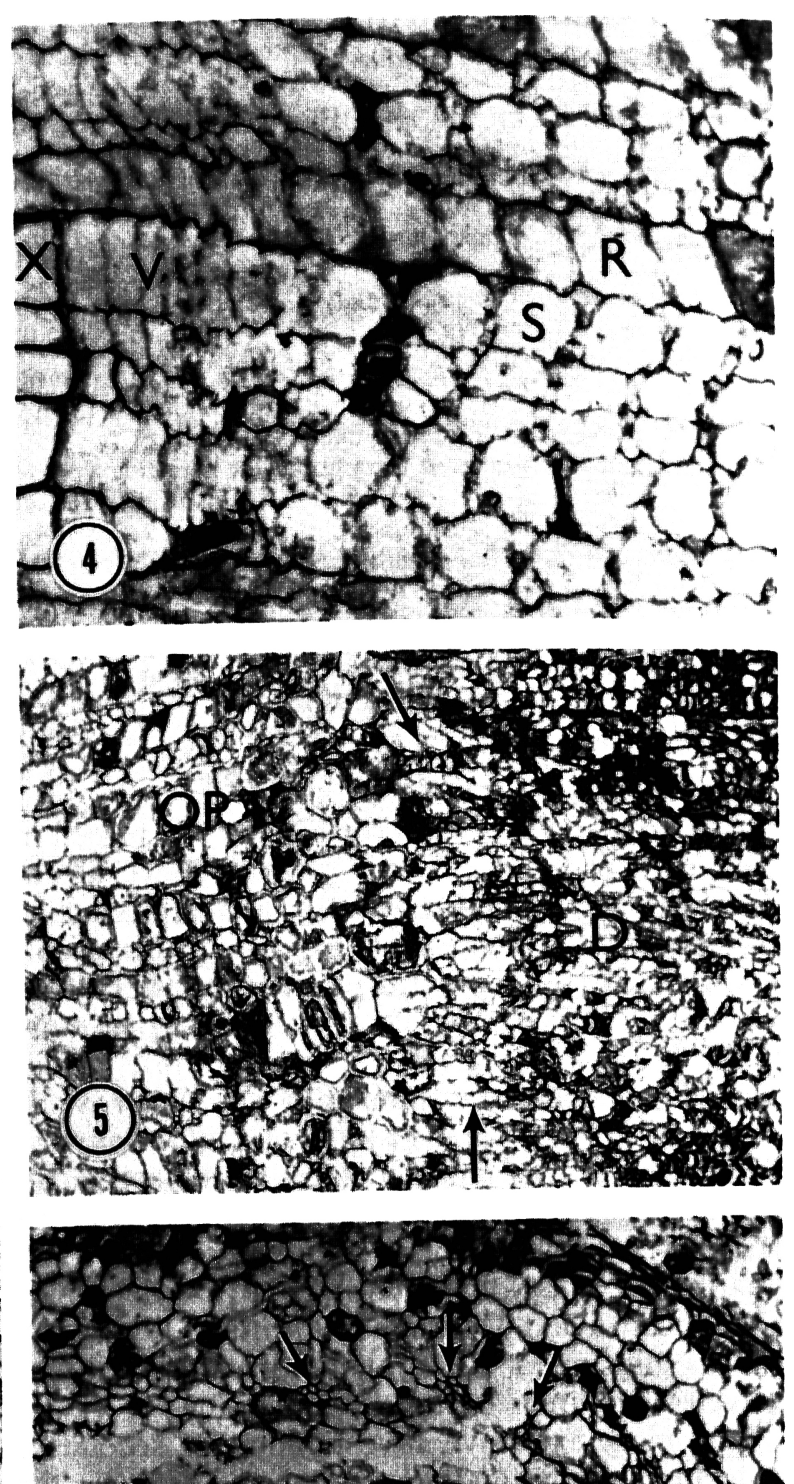

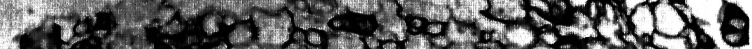

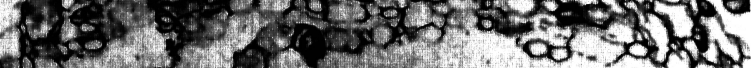

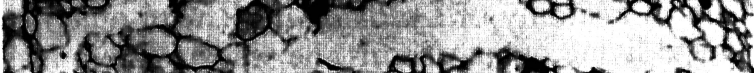
- if

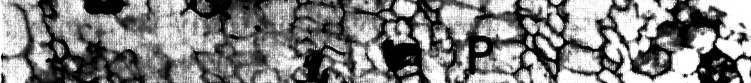

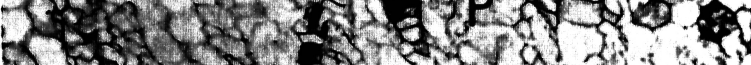

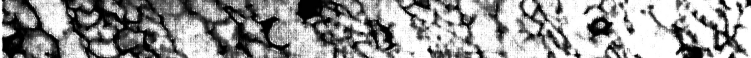

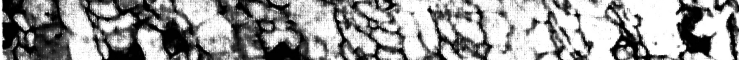

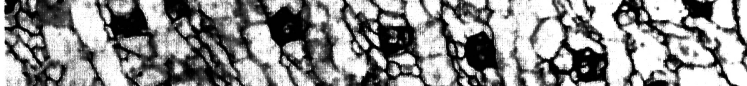

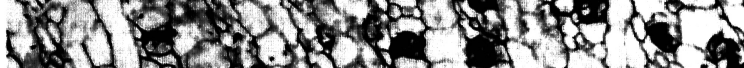
12 be

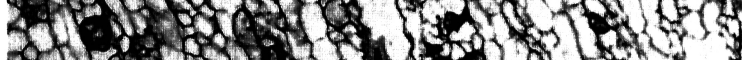

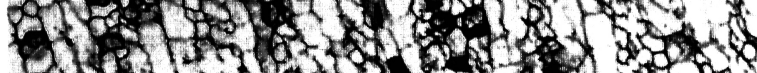

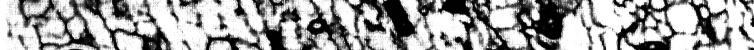
(6) 1 (6) 
TABLE 1

XYLEM AND PHLOEM PRODUCTION IN CALLISTOPHYTON BOYSSETII

\begin{tabular}{|c|c|c|c|c|c|c|c|}
\hline \multirow{2}{*}{$\begin{array}{l}\text { COAL BALL } \\
\text { NO. }\end{array}$} & \multirow{2}{*}{\multicolumn{3}{|c|}{$\begin{array}{c}\text { STEM DIAMETER } \\
(\mathbf{m m})\end{array}$}} & \multicolumn{2}{|c|}{ WIDTH $(\mathbf{m m})$} & \multicolumn{2}{|c|}{$\begin{array}{l}\text { NO. CELLS/RADIAL } \\
\text { ROW }\end{array}$} \\
\hline & & & & $2^{\circ}$ xylem & $2^{\circ}$ phloem & Xylem & Phloem \\
\hline 303 B top & 7.4 & $\mathrm{x}$ & 13.1 & 2.0 & $1.25(1.5)$ & 27 & 56 \\
\hline 303 B top & 7.5 & $\mathrm{x}$ & 13.8 & 2.0 & $1.30(1.7)$ & 26 & 50 \\
\hline 303 B top & 7.5 & $\mathrm{x}$ & 13.8 & 1.8 & 1.05 & 26 & 38 \\
\hline 979 F top & 7.0 & $\mathrm{x}$ & 9.5 & 1.75 & $1.05(1.18)$ & 24 & 37 \\
\hline 303 A & 7.2 & $\mathrm{x}$ & 13.8 & 2.01 & 1.25 & 25 & 50 \\
\hline 303 A & 7.2 & $\mathrm{x}$ & 13.8 & 2.01 & 1.25 & 28 & 46 \\
\hline 979 D, bot & 7.0 & $\mathrm{x}$ & 12.0 & 1.95 & $1.25^{*}$ & 29 & 25 \\
\hline 979 E, bot & 7.0 & $\mathrm{x}$ & 10.0 & 1.75 & $.95(1.25)^{\mathrm{H}}$ & 24 & 41 \\
\hline 979 E, bot & 7.0 & $\mathrm{x}$ & 10.0 & 1.75 & .95 & 23 & 39 \\
\hline 979 F bot & 6.0 & $\mathrm{x}$ & 9.2 & 1.70 & $1.00(1.25)^{\mathrm{H}}$ & 24 & 40 \\
\hline 979 F bot & 6.0 & $\mathrm{x}$ & 9.2 & 1.70 & 1.00 & 23 & 37 \\
\hline
\end{tabular}

NOTE.-Numbers listed first represent inner phloem. Numbers in parentheses are the inner plus the outer phloem. Inner phloem includes all the cells from the cambium out to either the primary cortex or the area of extensive wall thickening and associated histological changes (the outer phloem). The width of the outer phloem zone is difficult to measure accurately because of the histological changes that disrupt the position of the cells within the secondary phloem.

${ }^{8}$ No histological changes in the peripheral secondary phloem were present in this specimen. The secondary phloem could be measured out to the primary cortex.

b Although changes in the peripheral secondary phloem cells were present, the cells were not totally disrupted, and the width of the zone of phloem could be measured out to the primary cortex.

periderm) tissue on the outside. The cambial zone varies in width but is generally three to four cells wide. Initials are rectangular in cross section and are distinguished from mature phloem by their relatively small diameter (ca. $49 \mid \mathrm{xm}$ ), especially radial diameter (26 $\mathrm{xm}$ ), and their thin walls (fig. $4)$.

\section{PHLOEM ANATOMY}

GENERAL.-The width of the secondary phloem zone, as measured in relatively uncrushed sections, ranges from 0.95 to $2.0 \mathrm{~mm}$. The tissue consists of an axial system of alternating, tangential bands of sieve elements and phloem parenchyma with scattered secretory cells (fig. 1). Phloem rays are simple and continuous with the secondary xylem rays (fig. 4). In some younger stems, the tissue is bordered on the outside by primary cortical cells (figs. 2, 3, 6). In a few specimens (figs. 3, 6), groups of narrow, somewhat thick-walled cells are present at the outer edge of the secondary phloem, and these may represent primary phloem strands.
Each strand consists of relatively thin-walled, larger cells that may represent sieve elements, mixed with smaller thick-walled cells, possible phloem parenchyma (fig. 3). In addition, a few strands are closcly associated with cells containing dark contents that have been called secretory cells (fig. 3 ). These presumed primary phloem bundles are evenly distributed around the circumference of the axis within the cortex (fig. 6). In longitudinal section (fig. 13), the cells are generally too crushed to discern sieve areas or pores.

In most of the older stems, a phellogen is present in the outer secondary phloem (figs. 5, 16), and this serves to disrupt the outer phloem cells and prevent an accurate measurement of the total width of the secondary phloem zone. With just one exception (table 1), the phloem zone was always narrower than the secondary xylem but generally contained many more cells per radial row than the corresponding row of tracheids. In each case, both the xylem and phloem derivatives of a single fusiform initial were measured. Assuming that some

FIGS. 1-6.-Phloem of Callistophyton boyssetii. Fig. 1, Cross section of a portion of the stem. Xylem below; phloem, cortex, and periderm above. Note dark secretory cells (arrows) within secondary phloem; $979 \mathrm{~F}$ top, no. 2; X 40. Fig. 2, Detail of peripheral phloem with primary cortical cells above. Although histological changes are present in the outer phloem, radial rows (arrows) can still be followed out to cortex. Periderm visible upper right corner. 979 E, bot, no. 15; X 60. Fig. 3, Cross section through peripheral secondary phloem. Arrow indicates presumed primary phloem bundle within cortical tissue; 979 E, bot, no. 15; $x$ 130. Fig. 4, Cross section through cambial zone; 303 A, no. 22; $x$ 160. Fig. 5, Cross section illustrating disruption of secondary phloem following formation of periderm. Outer phloem left, phellem right. Arrows indicate approximate position of phellogen; 303 A, no. 22; x 70. Fig. 6, Cross section through stem showing continuity of tissue from secondary xylem to cortex. Arrows indicate presumed bundles of primary phloem; $979 \mathrm{D}$, bot, no. 1 ; x 55 . C = cortex, $D$ » phellem, IP » inner phloem, $O P=$ outer phloem, $P=$ secondary phloem, $R=$ phloem ray, $S=$ sieve cell, $V=$ vascular cambium, $X=$ secondary $x y l e m$. 
secondary phloem would be lost or badly disrupted during the development of the periderm, specimens with no phellogen forming in the phloem should provide an accurate estimate of the relative proportions of xylem and phloem. These specimens clearly indicate that the production of xylem and phloem by the vascular cambium was unequal, although a few specimens show an approximate 1:2 ratio of xylem to phloem in number of cells produced (table 1, 24:41, 24:40).

The widths of the xylem and phloem zones do not appear to be directly correlated with the overall diameter of the axis, although the larger axes generally possess slightly more secondary tissue than the smaller axes (table 1). The relative proportions of secondary tissues may have been affected by age or environmental factors as they are in living plants and, therefore, would vary from plant to plant. In addition, the distribution of the tissues may also vary, depending on position in the stem and proximity to leaf traces or branches. It is especially difficult to quantify this aspect of development in fossil plants, since the specimens may have been affected by crushing and distortion prior to fossilization. In Callistophyton, the shape and size of cells can be further distorted by histological changes in the outer phloem and by the production of periderm tissues.

SECRETORY CELLS.-Secretory or resinous cells were observed in the axial system of the stems but not in the rays. Some ray cells with dark contents were occasionally noted, but these were generally associated with the older phloem (figs. 7, 11, 16) and were histologically different from the secretory cells elsewhere in the phloem. The resinous cells in the inner portion of the phloem are similar to those in the pith and cortex, are noticeable within a few cells of the cambial zone (figs. 4, 6), and are generally randomly scattered throughout the secondary phloem. In a few specimens (fig. 6), resinous cells appear to be oriented in tangential bands. These cells may replace a single sieve cell, one or two phloem parenchyma cells, or an entire tangential band of parenchyma-up to four cells. In cross section, secretory cells may be rectangular, like the adjacent sieve cells, but in many specimens they have undergone some enlargement and are more spherical (fig. 6). In longitudinal section, resinous cells sometimes resemble elongate canals (figs. 14, 16), but in other cases, cross walls are clearly evident (figs. 17, 21).

AXIAL PARENCHYMA.-The bands of phloem parenchyma range from two to four cells wide tangentially but are only rarely more than one cell thick radially (fig. 15). The alternating pattern of sieve cells and phloem parenchyma is very regular, and only occasionally is the pattern disrupted by the loss of a row of parenchyma cells. Immediately adjacent to the cambium, the phloem parenchyma cells are relatively undistorted, but within a distance of five or six cells from the cambium, the central cells in each band become flattened (fig. 4). This crushing may be due to a slight increase in diameter of the adjacent sieve cells. Closer to the periphery of the secondary tissue, the axial parenchyma cells often become circular in cross section (fig. 11) (see Changes in outer phloem). The mean diameter of parenchyma cells close to the cambium is $21 \times 25$ fjLm, and those at the periphery are ca. $19 \times 24$ $\mathrm{xm}$ in diameter. In longitudinal section, the cells are rectangular (figs. 14, 21) and range from 104 to $215 \mathrm{fxm}$ long $($ mean $=164 \mathrm{xm})$.

VASCULAR RAYS.-Phloem rays are continuous with the xylem rays and are generally two cells wide, although they may range up to three cells wide (fig. 6). Outward from the cambium, the rays undergo considerable tangential expansion due almost entirely to cell enlargement; e.g., the diameter of the xylem rays at the level of the vascular cambium is ca. $41 \mathrm{lxm}$, while the phloem rays just a few cells away have already expanded to ca. 60 jim wide. Toward the periphery of the inner phloem, the rays expand considerably and can extend up to $353 \mathrm{lxm}$ wide. Although occasional cell divisions are observed, the major part of this expansion is caused by tangential stretching of the ray cells (figs. 3,8). A typical ray cell changes from a mean tangential diameter of $26 \mathrm{fxm}$ near the cambium to ca. $82 \mathrm{p}, \mathrm{m}$ at the periphery of the phloem; at the same time, there is a decrease in the radial diameter of the cells. Some rays in cross section do not extend all the way to the cambium, and RUSSIN (1981) suggested that these may have been formed from declining fusiform initials. Occasional production of this type of ray would account for the broad range of ray sizes seen in tangential sections. Small, uniseriate and biseriate rays may be up to seven cells high, along with biseriate and triseriate rays more than 200 cells high (fig. 10).

SIEVE CELLS.-The sieve elements in Callisto-

FJGS 7-11. Phloem of Callistophyton boyssetii. Fig. 7, Radial section showing thickening of ray cells (center) and conducting elements (arrow) in transition from inner to outer phloem; $979 \mathrm{~F}$, side, no. 11; $x$ 55. Fig. 8, Cross section through periphery of outer phloem zone illustrating enlarged ray cells with dark-colored contents; 303 A, no. 22; $x$ 110. Fig. 9, Tangential section illustrating crushing of sieve cells (arrow) at periphery of secondary phloem. Arrowhead denotes sieve areas'in intact sieve cell; $979 \mathrm{E}$, side, no. I; x 130. Fig. 10, Tangential section illustrating large and small rays. Note sieve areas on sieve cells (arrowheads); 979 E, side, no. 6; $x$ 140. Fig. 11, Cross section illustrating histological changes during transition from inner to outer phloem. Thickening of cell walls in sieve cells and axial parenchyma usually precedes occlusion of cell lumen seen in the outermost phloem (center); 979 F top, no. 2; $x$ 140. $A *$ axial parenchyma, C - cortex, $I P=$ inner phloem, $O P=$ outer phloem, $R=$ phloem ray, $S *$ sieve cell. 

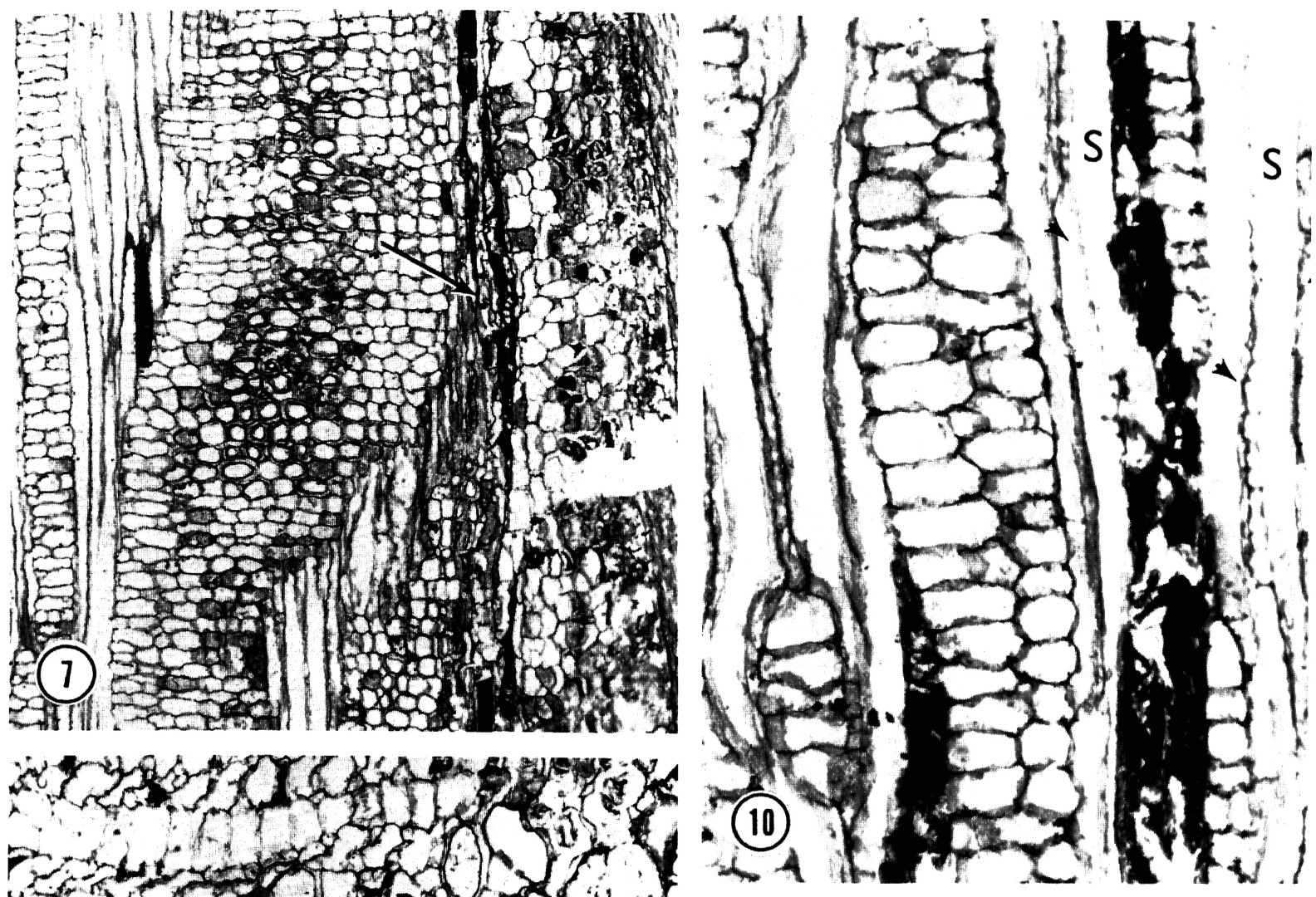

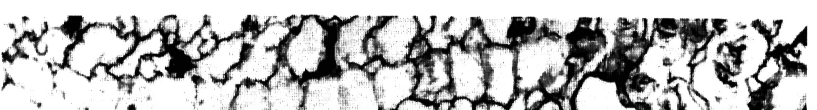

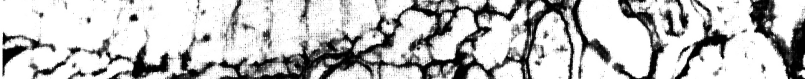

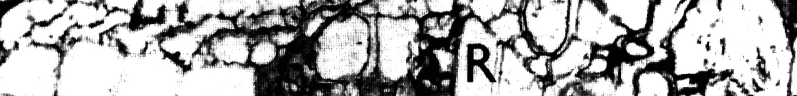

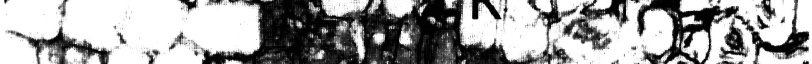

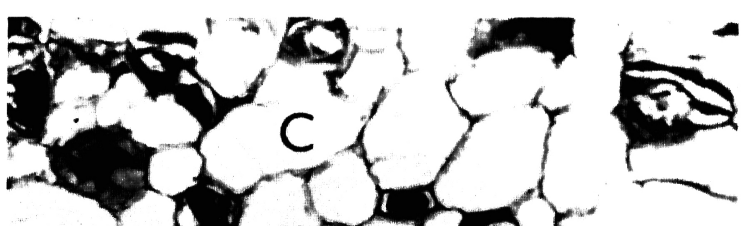

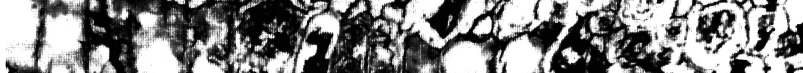

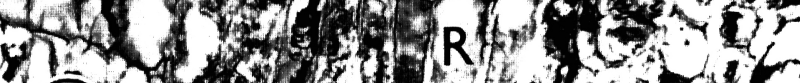

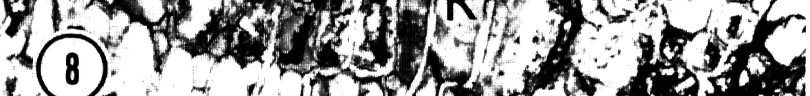

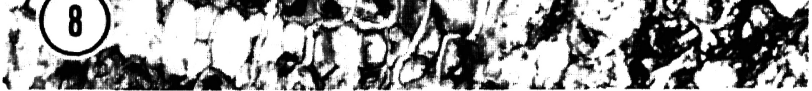
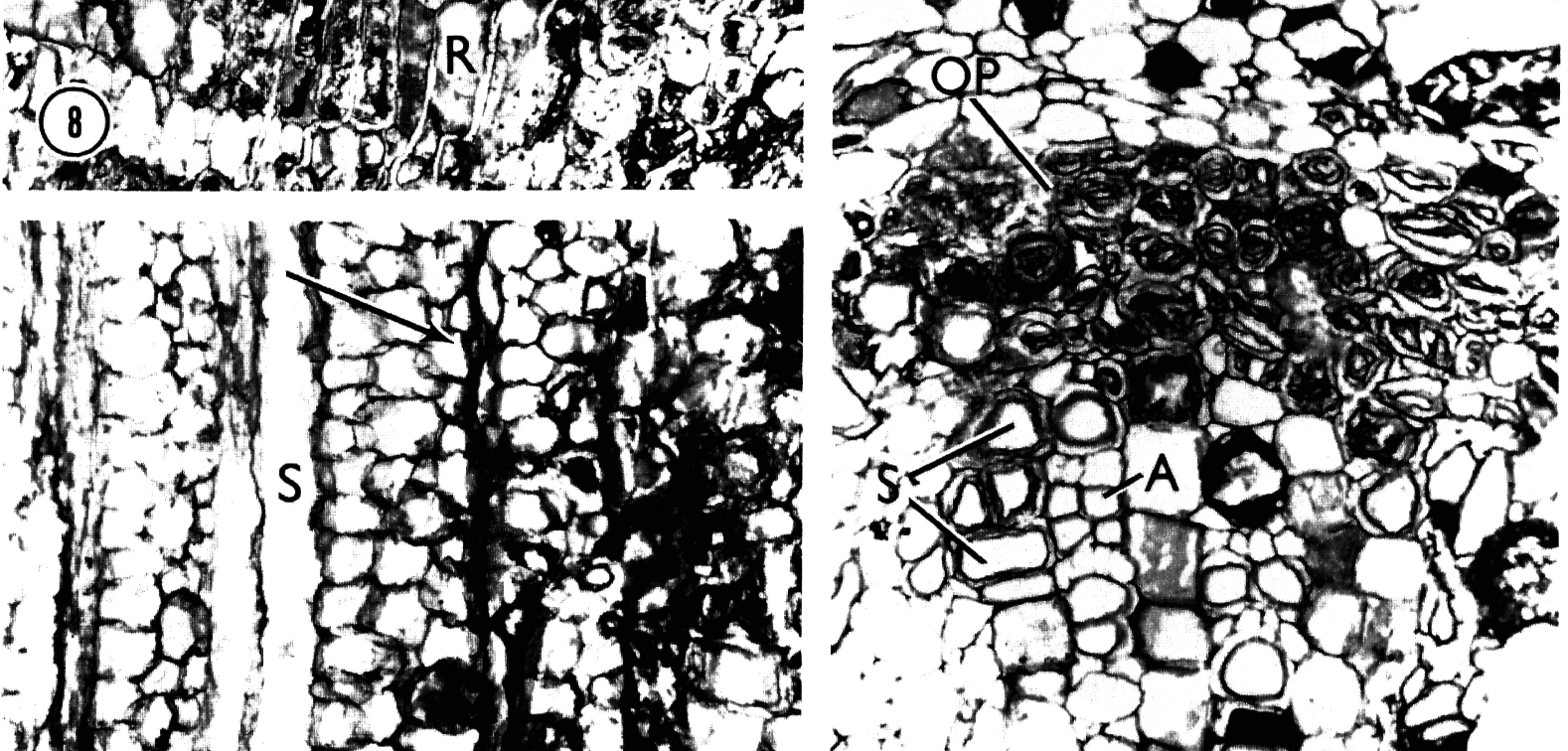

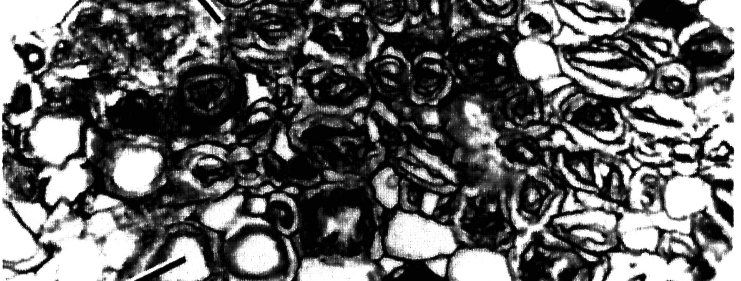
f.

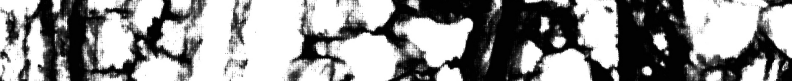

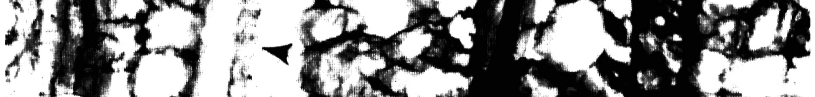

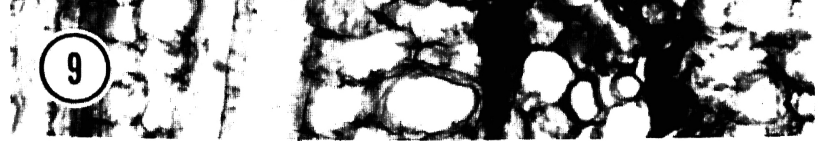
(11) 


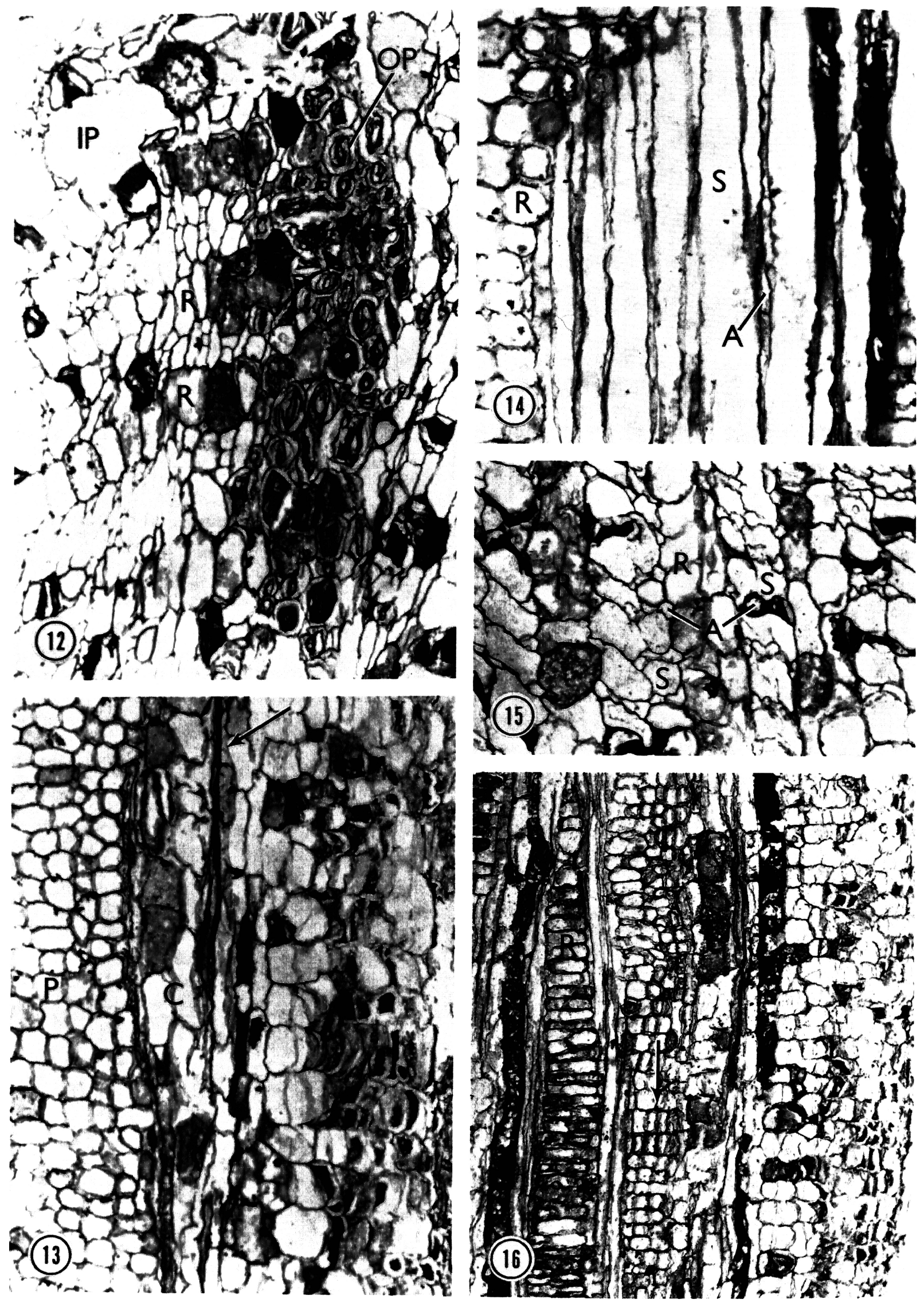


phyton are elongate with extremely tapered end walls (fig. 10). Sieve areas are similar on both end and side walls, indicating that these cells should be classified as sieve cells. In cross section, they vary from slightly flattened tangentially to almost circular in outline and range from $28 \times 38$ fxm to 80 $\mathrm{X} 99 \mathrm{fxm}$ in diameter (fig. 15). Although there is a change in cell diameter from the xylem across the vascular cambium to the phloem, the difference between the mean diameter of the tracheids next to the cambium $(62 \mathrm{xm})$ and the sieve cells $(53 \times 73$ $\mathrm{lim}$ ) is not very large (figs. 1,4). Sieve cells are extremely long, up to $1.7 \mathrm{~mm}$, with no evidence of an end wall. Numerous, crowded sieve areas are present on radial and end walls. These are usually oval (figs. 19, 20) but quite variable. In some cases, each sieve area is truncated and appears almost rectangular (figs. 22, 23); in other instances, elongate and tapered (figs. 19, 20). Relatively light-colored sieve areas (fig. 18) are interpreted to represent little callose deposition, and very dark-colored sieve areas (figs. 22, 23) have been interpreted as definitive callose deposits (RUSSIN 1981). Those intermediate between these two extremes (fig. 20) may represent pores lined with callose.

CHANGES IN THE OUTER PHLOEM.-A number of histological differences between the inner and outer phloem are evident in this material. Inner phloem includes those cells from the most recently formed phloem adjacent to the cambium out to the zone of thick-walled phloem elements (figs. 1, 11, 12). Outer phloem consists of the more peripheral, thickwalled cells. These two terms are purely arbitrary and do not relate to the terms "inner bark" and "outer bark" used in some studies dealing with anatomy of extant plants, since these designations apply not only to structural features but often to functional changes as well.

One of the first recognizable changes in the older cells of the inner phloem is an enlargement in the tangential diameter of the ray cells (figs. 8, 12). This increase does not result in much disruption of the sieve cells, however, probably because of a concomitant increase in the circumference of the stem. For the most part, the ray cells seem to be passively stretched, since their tangential diameter increases from the cambium outward, while the radial diameter decreases from 65 fxm near the cambium to $45 \mathrm{fxm}$ at the periphery (both means, no. $=50)$. These ray cells often have dark-colored cell contents at this stage (fig. 8).

At about the same distance from the cambium that the rays begin to increase in size, the phloem parenchyma cells also increase in diameter until they appear circular in cross section (figs. 2, 11). This expansion sometimes results in a slight flattening of the adjacent sieve cells, which become more rectangular in cross section. Within about six to eight rows from the beginning of these changes in cell size, there is a rapid change within two or three cell layers from relatively normal-looking phloem to obviously altered and nonfunctional phloem. The sieve cells undergo a change in wall thickness and expand in tangential diameter (from 73 to $81 \mid \mathrm{xm}$ ), becoming rounder (fig. 11). At about the same level, the axial parenchyma and ray cells also develop thickened walls so that they are generally not crushed by the enlarged sieve cells (figs. 11, 12). All cells contain dark contents at this stage. The result of the general increase in wall thickness and diameter of the secondary phloem is that some cells are crushed (fig. 9) and the radial rows of phloem cells become extremely disrupted. In many instances, it is impossible to trace a single row of conducting cells or a phloem ray out to the cortical cells. In longitudinal section, die thickening of ray cell walls is especially conspicuous (figs. 7, 16), and dark contents within the axial cells are also apparent (fig. 9).

PERIDERM- - A discontinuous cork cambium differentiates in the outer cortex and begins to produce phellem at a stage when the secondary vascular tissues are well developed (fig. 1). As the outer cortex and epidermis are sloughed off, successive phellogens are formed, first in the primary cortex (figs. 2, 13) and later at the outer edge of the secondary phloem (fig. 16). Consequently, in older stems (fig. 5), the extraxylary tissues consist of inner (presumably functional) phloem, outer (presumably nonfunctional) phloem, and periderm.

\section{Discussion}

Callistophyton stems with well-preserved phloem have been described more often than probably any other fossil plant. DELEVORYAS and MORGAN (1954) illustrated secondary phloem containing sieve cells that exhibited the remnants of sieve areas and possible callose plugs on their radial walls. Tangential bands of phloem parenchyma and phloem rays were also present. Unlike species of Poroxylon Renault

FIGS. 12-16.-Phloem of Callistophyton boyssetii. Fig. 12, Cross section through outer phloem zone showing dark-colored contents in phloem cells and disruption of radial rows; $979 \mathrm{~F}$ top, no. 2; x 140. Fig. 13, Longitudinal section through outermost secondary phloem, cortex, and periderm. Arrow indicates possible primary phloem cells; 979 F, side, no. 11; x 120. Fig. 14, Radial section showing phloem ray, secretory cells (dark cells, right), sieve cells, and strand of axial parenchyma; $979 \mathrm{~F}$, side, no. 11; $x$ 160. Fig. 15, Cross section illustrating alternating pattern of sieve cells and axial parenchyma, separated by phloem rays; $979 \mathrm{~F}$ top, no. 3; $x$ 150. Fig. 16, Longitudinal section through outermost secondary phloem (left) and periderm (right). Note enlarged ray cells' and formation of periderm within ray (arrow); $979 \mathrm{E}$, side b, no. 6; x 65. A - axial parenchyma, C cortex, $I P=$ inner phloem, $O P=$ outer phloem, $P=$ secondary phloem, $R=$ phloem ray, $S$ « sieve cell. 


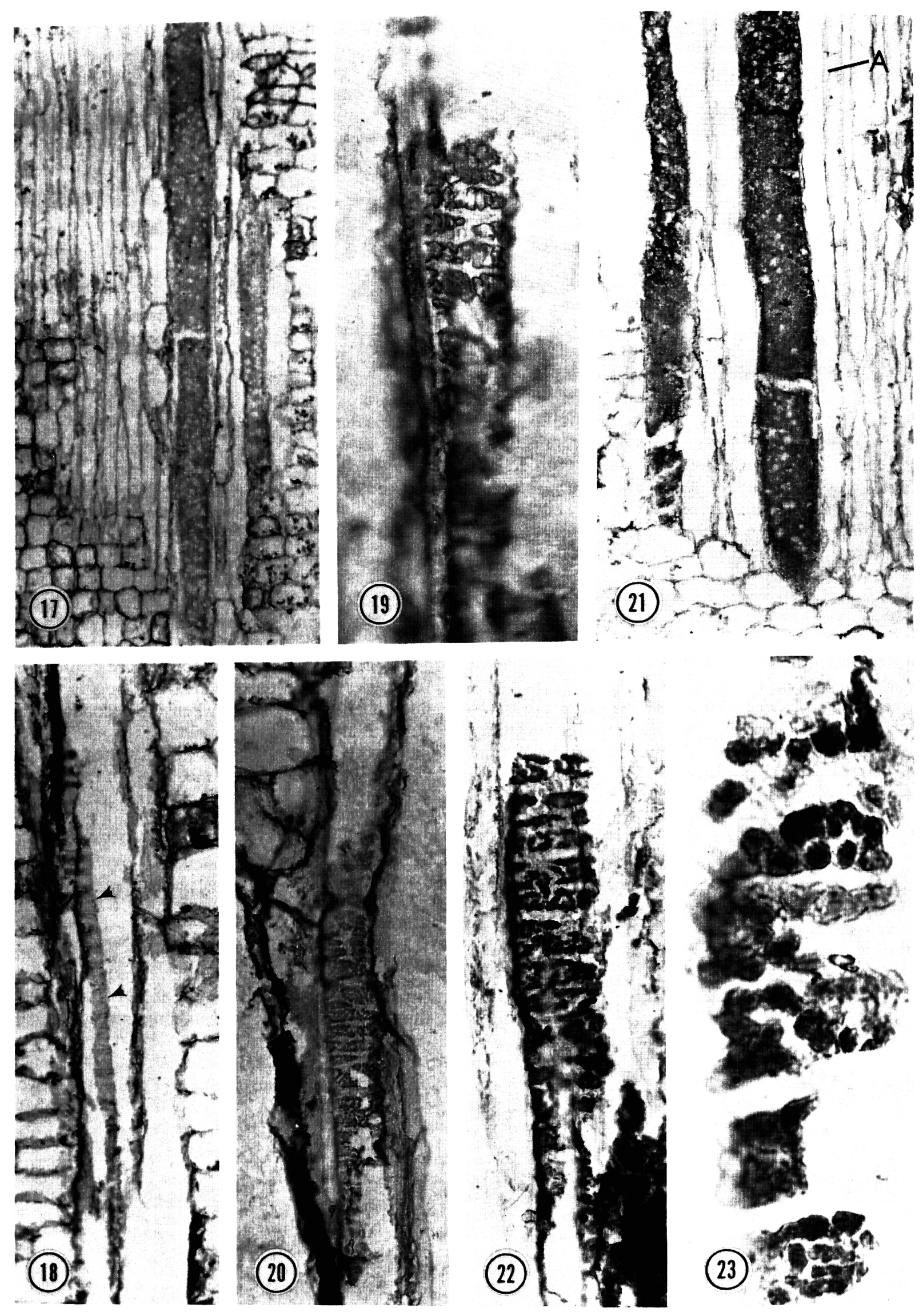


from France, $C$. poroxyloides contained no secretory cavities in the phloem (DELEVORYAS and MORGAN 1954). ROTHWELL (1975) found not only preserved secondary phloem but also occasional examples of primary phloem cells. Secretory or resinous cells were present in the secondary phloem of C. boyssetii. Toward the periphery of the zone of secondary phloem in this taxon, ROTHWELL (1975) noted histological changes, including the presence of thick-walled cells that he compared with the sclereids in some living plants (Pseudotsuga; GRILLOS and SMITH 1959), but no detailed examination of these changes was completed.

The earliest studies on Callistophyton phloem were a series of papers on Poroxylon from the Permo-Carboniferous of Autun and Grand'Croix, France (RENAULT 1879, 1880; BERTRAND and RENAULT 1886; BERTRAND 1889). ROTHWELL (1975) placed $P$. edwardsii (RENAULT 1880) and $P$. boyssetii (RENAULT 1879) in synonymy under the binomial C. boyssetii. BERTRAND and RENAULT (1886) described and figured beautifully preserved, silicified stems containing sieve cells with numerous sieve areas on their radial walls. They found three types of sieve areas: (1) degraded ones; (2) small, rounded sieve areas with relatively few pores; and (3) larger areas with numerous, closely spaced pores. The larger sieve areas were present in transverse bands that covered the entire width of the radial wall (BERTRAND and RENAULT 1886; BERTRAND 1889). The North American material exhibits a similar diversity in shape and size of sieve areas (figs. 18-20, 22, 23).

One of the most interesting aspects of the work of BERTRAND and RENAULT (1886) is their description of histological changes that occur toward the periphery of the secondary phloem zone in Poroxylon. They found that all the elements were somewhat flattened near the cambium. Further out, the axial parenchyma cells enlarged slightly, partially flattening the sieve cells between them. Toward the periphery of the secondary tissue, the sieve cells also began to enlarge; the walls of both the parenchyma and the conducting cells thickened; and the ray cells enlarged tremendously. All these changes were observed in the North American Callistophyton specimens as well. However, the French material differs from the stems described here by abundant radial and tangential divisions in the ray cells near the periphery of the phloem. In the oldest stems, BERTRAND and RENAULT (1886) found that the secondary phloem abutted on cells of the periderm, as in the North American specimens.

RUSSIN'S (1981) description of Callistophyton phloem, based on coal ball specimens of C. poroxyloides and $C$. boyssetii, is generally similar to my material, with a few exceptions. Concerning the proportions of secondary xylem and phloem, RUSSIN found that axes with little secondary development had secondary xylem with little phloem, and older axes had relatively equal amounts of secondary xylem and phloem. These different proportions were not observed in the present material. There are several possible explanations for this discrepancy. In extant plants, the relative amounts of xylem and phloem produced by the cambium can vary with the age of the plant, time of year, and other environmental factors (ARTSCHWAGER 1950; BANNAN 1955; GRILLOS and SMITH 1959). In extant cycads, CHAMBERLAIN (1911) reported the following proportions of secondary xylem and phloem: $3: 2,1: 1,1: 1,10: 1.4$. The number of phloem cells that are visible in each radial row in Callistophyton depends on the histological changes that take place in the older phloem as well as on the timing of periderm production.

There is very little information from the fossil record on the relative production of xylem and phloem by the cambium. In Heterangium americanum, HALL (1952) found that secondary phloem may equal or exceed secondary xylem, but this observation was based on only one specimen. In $H$. grievii (WILLIAMSON and SCOTT 1896), the amount of secondary xylem apparently exceeded the phloem, while in $H$. tiliaeoides, the ratio varied from slightly more xylem than phloem (WILLIAMSON 1887; WILLIAMSON and SCOTT 1896) to approximately equal amounts of the two tissues (WILLIAMSON 1887; SCOTT 1923). In Lyginopteris, the production of secondary xylem greatly exceeded that of secondary phloem (WILLIAMSON and SCOTT 1896), and STIDD and PHILLIPS (1973) found a similar situation in Schopfiastrum (xylem/phloem $=8: 1$ ) (see also ROTHWELL and TAYLOR 1972). These examples illustrate the difficulty in assessing the relative contribution by the cambium to xylem and phloem in fossil plants. The available information is generally based on one or two specimens, and poor preservation is much more likely to affect the amount of phloem tissue than the amount of xylem. At this time, the available data on the relative proportions of xylem and phloem are too meager to place any

FIGS. 17-23.-Phloem of Callistophyton boyssetii in longitudinal section. Fig. 17, Radial section of secondary phloem, showing secretory cells with numerous primary pit fields; $979 \mathrm{E}$, side, no. 9; x 120. Fig. 18, Tapered end wall of sieve cell with sieve areas (arrowheads); $979 \mathrm{E}$, side, no. 6; x 208. Fig. 19, Degraded sieve areas on sieve-cell wall; $979 \mathrm{~F}$, side b, no. 6; $x 480$. Fig. 20, Radial section showing irregularly shaped sieve areas; 979 E, side, no. 6; x 350. Fig. 21, Secondary phloem illustrating two secretory cells with primary pit fields on their walls and dark contents; 979 E, side, no. 9; x 176. Fig. 22, Sieve areas with numerous callose plugs; $979 \mathrm{E}$, side, no. 1; x 400. Fig. 23, Detail of sieve areas with presumed callose covering sieve pores; $979 \mathrm{E}$, side, no. 3 ; $\mathrm{x}$ 1,600. $A=$ axial parenchyma. 
taxonomic or phylogenetic importance on this feature alone.

Some of the differences between RUSSIN's (1981) data and mine may represent merely an artifact introduced during the size analyses. RUSSIN measured a large number of radial rows but apparently did not compare the number of phloem cells and xylem cells within a single radial row. Generally, he measured about five times as many xylem rows as phloem ones (table 1 in RUSSIN [1981]). In the one instance where the number of rows was close to equal (five phloem rows, seven xylem), the data indicated that there were approximately twice as many xylem cells (53) as phloem (28). In addition, according to RUSSIN, the cambium in Callistophyton would have to produce initially more xylem than phloem (xylem present, but little phloem) and then produce relatively more phloem for a period of time, so that the overall proportions of the two tissues would become more equal with development. Presumably, as the ratio approached one, the production of phloem would slow down and eventually equal the production of xylem.

In extant gymnosperms, the composition of the secondary phloem and the arrangement of the cells have taxonomic and presumably evolutionary significance (HOLDHEIDE 1951; CHANG 1954). This also appears to be the case in the Paleozoic seed ferns that have been examined. The pattern of alternating bands of sieve cells and phloem parenchyma has been observed almost universally in the secondary phloem of Carboniferous seed ferns, excluding the medullosans (SMOOT 1984). In Callistophyton, this pattern is very regular, and the uniseriate bands are only rarely interrupted by the loss of a band of axial parenchyma. The same situation apparently exists in Heterangium (HALL 1952), Microspermopteris (TAYLOR and STOCKEY 1976), Lyginopteris (WILLIAMSON and SCOTT 1896), and Calamopitys (GALTIER and HSBANT 1973). In Calamopitys, the bands of sieve cells may be one to two cells wide radially, but in all the other taxa they are limited to one cell layer. Since Calamopitys represents the oldest material (Lower Carboniferous as opposed to Upper Carboniferous for the North American and British material) that has been investigated, perhaps the more regular arrangement of the bands of sieve cells represents a derived feature. DEN OUTER (1967) suggested a similar trend based on the comparative anatomy of extant gymnosperms.

The arrangement of secondary phloem cells in Callistophyton and other Carboniferous seed ferns has no parallel in extant plants. Among the living gymnosperms, only members of the Pinaceae and the Gnetales have phloem that consists exclusively of sieve cells and parenchyma. In some cases, the secondary phloem consists primarily of sieve cells, with axial parenchyma strands scattered throughout or present in poorly organized, tangential bands (DEN OUTER 1967; ESAU 1969). Examples of this type are Pseudotsuga (GRILlOS and SMITH 1959; DEN OUTER 1967) and some species of Pinus (SRIVASTAVA 1963a; ESAU 1969). In other taxa \{Abies and some species of Pinus), the sieve cells and phloem parenchyma regularly alternate as they do in Callistophyton, but the bands of sieve cells vary from 5 to 15 cells wide (CHANG 1954; ALFIERI and EVERT 1968; ESAU 1969). In the Gnetales, the axial parenchyma is either randomly scattered, as in Ephedra, or in radial files, as in Gnetum (ESAU 1969). Sclereids often develop in the older phloem of this group, much as they do in Callistophyton. The great majority of gymnosperms, however, including most of the conifers, cycads, and Ginkgo, have fibers in their secondary phloem (CHANG 1954; SRIVASTAVA 1963b; DEN OUTER 1967; ESAU 1969) and thus cannot be directly compared with Callistophyton, even at the broadest level of cellular composition. Numerous conifers show a regular pattern of alternating tangential bands, but the bands consist of sieve cells, axial parenchyma, sieve cells, fibers, etc., in that order (CHANG 1954; DEN OUTER 1967; ESAU 1969).

The histological changes that take place in the outer phloem cells of Callistophyton have been observed in a number of extant plants and there represent changes from functional to nonfunctional phloem (SRIVASTAVA 1964; ESAU 1969). Most of the studies completed on this subject were concerned with conifer phloem, and these have shown that deposition of definitive callose is one of the first stages in the process (SRIVASTAVA 1963a; ALFIERI and EVERT 1968). Subsequently, the phloem parenchyma and ray parenchyma cells enlarge and appear rounder in cross section, usually crushing sieve cells and albuminous cells as they increase in size. Some parenchyma cells may also divide (ISENBERG 1943; GRILLOS and SMITH 1959; SRIVASTAVA 1963a). In some taxa, sclereids develop from parenchyma cells \{Abies, CHANG [1954]; Pseudotsuga, GRILlos and SMITH [1959]). Some of these may grow intrusively and greatly disrupt the cell patterns that were present in the functional phloem. SRIVASTAVA (1963a) concluded that sclereids were restricted to the nonfunctional phloem, although in some taxa they differentiated fairly close to the cambium.

The changes in the peripheral phloem of Callistophyton are unique when compared with those of extant taxa, because there is evidence that not only the parenchyma cells but also the sieve elements differentiate into sclereids in the older phloem. In angiosperms, although the sieve element is not considered to be dead at maturity, disintegration and disappearance of the nucleus are well-known 
aspects of sieve-element ontogeny. In gymnosperms, degeneration of the nucleus is pycnotic; nuclear material condenses, and remnants of it may persist within the sieve cell (EVERT 1977; ALFIERI and KEMP 1983). The evidence for further differentiation of the sieve elements in Callistophyton into sclereids is clear (fig. 11) and was also noted by BERTRAND and RENAULT (1886).

Because this situation has not been observed in extant phloem, the possibility that the sieve elements in Callistophyton were structurally or functionally different in some ways from those of living plants should not be overlooked. Perhaps the nucleus remained sufficiently active to function during the deposition of cellular contents and wall thickening that occurred in the peripheral sieve elements. On the other hand, the dark material in the peripheral sieve cells may not represent wall thickening but the intracellular deposition of substances such as tannins. In this case, the sieve element could play a passive role in the histological changes.

In an analogous situation, SCOTT (1899) observed what appeared to be thick-walled cells in Medullosa phloem (SмоOт 1984). Since these were the only cells preserved in the phloem, SCOTT (1899) described them as sieve cells and suggested that the cells may have undergone hydration and swelling after deposition, resulting in cell walls that appeared to be thickened in the fossil state but were thinner during the life of the plant. On the other hand, the rings of material within the peripheral sieve cells in Callistophyton may represent the plasma membrane and cytoplasm that collapsed following plasmolysis of the cells. However, the overall appearance of these thick-walled cells, their regular distribution in the peripheral phloem, and their absence elsewhere in the stem suggest that they are a normal part of development in the older phloem. In addition, a comparison of these cells with those described in both fossil and extant plants illustrates that they are histologically most similar to sclereids.

The increase in diameter of the stem in Callistophyton is initially accommodated by a tangential expansion of the ray cells and later by an increase in diameter of all the elements in the outer phloem during wall thickening. Occasional cell divisions have rarely been seen in ray cells. In living conifers, the tangential increase of the stem is accommodated by cell division (GRILLOS and SMITH 1959; SRIVASTAVA $1963<$ Z), tangential cell enlargement (stretching), including radial separation of cells, and occasional formation of a dilation tissue (ESAU 1969).

RUSSIN (1981) provided a comparison of phloem histology in Callistophyton, including such features as sieve-cell size and sieve area structure, with that described for other Paleozoic seed ferns, ex- tant cycads, and conifers. He concluded that sieve areas were found on radial walls in all three groups, but the appearance of the sieve areas and the length of sieve cells in Callistophyton were more similar to those in cycads than in conifers. CARLQUIST (1975), however, suggested that the length of fusiform initials may depend on such factors as water stress and mechanical strength in the tracheary elements, and he believes that the length of sieve-tube members is passively influenced by selective pressures on the xylem cells.

Some comparative work has been done on the significance of sieve-element length in the angiosperms (CHEADLE and WHITFORD 1941; ZAHUR 1959; DEN OUTER 1983), but no comparable data are available for gymnospermous sieve cells. The shape of the sieve elements and the location, size, and shape of sieve areas in all of the gymnosperms, living and fossil, are very similar. Some conifers, such as the Pinaceae, have sieve areas that appear rounder and less crowded than those in Callistophyton, but these characters have never been examined quantitatively, and any comparison between fossil and extant gymnosperms must, therefore, be subjective.

Many authors (e.g., WORSDELL 1906; STEWART and DELEVORYAS 1956) have suggested that the Paleozoic pteridosperms, especially the medullosans, may be ancestral to the extant cycads. On the basis of only phloem anatomy, the question of whether Callistophyton is more closely related to the conifers or the cycads is still uncertain. The fibers in Medullosa phloem and their absence in Callistophyton support a closer relationship with taxa that lack fibers, such as the cordaites or nonfibrous conifers, rather than with the extant cycads. In addition, the relative amount of parenchyma in the secondary phloem of Callistophyton appears to be less than that in Medullosa (SMOOT 1984), and this character may also indicate closer affinities with some conifers than with the cycads. On the basis of morphology and anatomy of both vegetative and reproductive organs, ROTHWELL (1981) suggested that the Callistophytales include characteristics of both the pteridosperms and conifers, and the data on phloem anatomy appear to support this suggestion.

\section{Acknowledgments}

I thank Dr. GILBERT A. LEISMAN, Biology Department, Emporia State University, Emporia, Kansas, and Dr. BENTON M. STIDD, Biology Department, Western Illinois University, Macomb, for their generous loan of specimens. This work was completed under the guidance of Dr. THOMAS N. TAYLOR, and I thank him for his advice and encouragement. Supported in part by National Science Foundation grant DEB-7908607, a grant-in- 
aid of research from Sigma Xi, the Scientific Research Society, and an Ohio State University Graduate School Alumni Research Award. This study was completed while I was on a fellowship from the Educational Foundation of the American Association of University Women.

\section{LITERATURE CITED}

ALFIERI, F. K., and R. F. EVERT. 1968. Seasonal development of the secondary phloem in Pinus. Amer. J. Bot. 55:518528.

ALFIERI, F. K., and R. I. KEMP. 1983. The seasonal cycle of phloem development in Juniperus californica. Amer. J. Bot. 70:891-896.

ARISCHWAGER, E. 1950. The time factor in the differentiation of secondary xylem and phloem in pecan. Amer. J. Bot. 37:15-24.

B ANN AN, M. W. 1955. The vascular cambium and radial growth in Thuja occidentalis. Can. J. Bot. 33:113-138.

BERIRAND, C.-E. 1889. Les Poroxylons: vegftaux fossiles du $l^{\wedge}$ poque houilliere. Ann. Soc. Belg. Microscop. M6m. 13:5-49.

BERTRAND, C.-E., and B. RENAULT. 1886. Recherches sur les Poroxylons-Gymnospermes fossiles des terrains houillers sup^rieurs. Arch. Bot. Nord France 2:243-389.

CARLOUIST, S. 1975. Ecological strategies of xylem evolution. University of California Press, Berkeley. 259 pp.

CHAMBERLAIN, C. J. 1911. The adult cycad trunk. BOT. GAZ. 52:81-104.

CHANG, Y.-P. 1954. Bark structure of North American conifers. U. S. Dep. Agr. Tech. Bull. 1095:1-86.

CHEADLE, V. I., and N. B. WHITFORD. 1941. Observations on the phloem in the Monocotyledoneae. I. The occurrence and phylogenetic specialization in structure of the sieve tubes in the metaphloem. Amer. J. Bot. 28:623-627.

DELEVORYAS, T., and J. MORGAN. 1954. A new pteridosperm from Upper Pennsylvanian deposits of North America. Palaeontographica 96B: 12-23.

DEN OUTER, R. W., 1967. Histological investigations of the secondary phloem in gymnosperms. Mededelingen Landbouwhogeschool Wageningen 67(7): 1-119.

- 1983. Comparative study of the secondary phloem of some woody dicotyledons. Acta Bot. Neerlandica 32:29-38.

ESAU, K. 1969. The phloem. Pages 322-338 in W. ZMMERMANN, P. OZENDA, and H. D. WULFF, eds. Handbuch der Pflanzenanatomie. Vol. 5, pt. 2. Borntraeger, Berlin. 505 pp.

EVERT, R. F. 1977. Phloem structure and histochemistry. Annu. Rev. Plant Physiol. 28:199-222.

GALTIER, J., and C. H£BANT. 1973. Sur le phloeme et le cambium d'une Calamopityac£e, pt6ridospermale probable du Carbonif\&re inf\&ieur frangais. Compt. Rend. Acad. Sci. Paris 276D:2257-2259.

GRILLOS, S. J., and F. H. SMITH. 1959. The secondary phloem of Douglas-fir. Forest Sci. 5:377-388.

HAL, J. W. 1952. The phloem of Heterangium americanum. Amer. Midland Natur. 47:763-768.

HOLDHEIDE, W. 1951. Anatomie mitteleuropaischer Geoholzrinden. Pages 193-367 in H. FREUND, ed. Handbuch der Mikroskopie in der Technik. Vol. 5. Umschau, Frankfurt.

ISENBERG, I. H. 1943. The anatomy of redwood bark. Madrono $7: 85-91$.

JOY, K. W., A. J. WILLIS, and W. S. LACEY. 1956. A rapid cellulose peel technique in paleobotany. Ann. Bot. 20:635637.

PHILUIS, T. L. 1980. Stratigraphic and geographic occurrences of permineralized coal-swamp plants-Upper Carboniferous of North America and Europe. Pages 25-92 in D. L. DILCHER and T. N. TAYLOR, eds. Biostratigraphy of fossil plants.
Dowden, Hutchinson \& Ross, Stroudsburg, Pa.

RENAULT, B. 1879. Structure comparee de quelques tiges de la flore Carbonifere. Mus. Nat. Hist. Natur. Nouvelles Arch T ser., 2:213-348.

- 1880. Sur une nouvelle espece de Poroxylon. Compt Rend. Acad. Sci. Paris 91:860-861.

ROIHWEL, G. W. 1975. The Callistophytaceae (Pteridospermopsida). I. Vegetative structure. Palaeontographica $151 \mathrm{~B}: 171-196$

1980. The Callistophytaceae (Pteridospermopsida). II. Reproductive features. Palaeontographica 173B:85-106.

-. 1981. The Callistophytales (Pteridospermopsida): reproducevely sophisticated Paleozoic gymnosperms. Rev. Palaeobotany Palynology 32:103-121.

ROTHWELL, G. W., and T. N. TAYLOR. 1972. Carboniferous pteridosperm studies: morphology and anatomy of Schopfiastrum decussatum. Can. J. Bot. 50:2649-2658.

RUSSIN, W. A. 1981. Secondary phloem of the Paleozoic pteridosperm Callistophyton boyssetii (Renault) Rothwell. BOT GAZ. 142:165-175.

SCOTT, D. H. 1899. On the structure and affinities of fossil plants from the Palaeozoic rocks. III. On Medullosa anglica. a new representative of the Cycadofilices. Phil. Trans. Roy. Soc. London 191B:81-126.

1923. Studies in fossil botany, 3d ed. Vol. 2. Spermophyta. A. \& C. Black, London. 446 pp.

SMOOT, E. L. 1984. Phloem anatomy of the Carboniferous pteridosperm Medullosa and evolutionary trends in gymnosperm phloem. BOT. GAZ. 145 (in press).

SRIVASTAVA, L. M. 1963A. Secondary phloem in the Pinaceae. Univ. Calif. Publ. Bot. 36:1-142.

1963Z?. Cambium and vascular derivatives of Ginkgo biloba. J. Arnold Arboretum 44:165-188.

-. 1964. Anatomy, chemistry, and physiology of bark. Int. Rev. Forest Res. 1:203-277.

STEWART, W. N., and T. DELEVORYAS. 1956. The medullosan pteridosperms. Bot. Rev. 22:45-80.

STEWART, W. N., and T. N. TAYLOR. 1965. The peel technique. Pages 224-232 in B. KUMMEL and D. RAUP, eds. Handbook of paleontological techniques. W. H. Freeman, San Francisco.

STIDD, B. M., and T. L. PHILLIPS. 1973. The vegetative anatomy of Schopfiastrum decussatum from the Middle Pennsylvanian of the Illinois basin. Amer. J. Bot. 60:463-474.

TAYLOR, T. N., and R. A. STOCKEY. 1976. Studies of Paleozoic seed ferns: anatomy and morphology of Microspermopteris aphyllum. Amer. J. Bot. 63:1302-1310.

WILLIAMSON, W. C. 1887. On the organisation of the fossil plants of the Coal-Measures. XIII. Heterangium tiliaeoides (Williamson) and Kaloxylon Hookeri. Phil. Trans. Roy. Soc. London 178:289-304.

WILLIAMSON, W. C., and D. H. SCOTT. 1896. Further observations on the organization of the fossil plants of the CoalMeasures. III. Lyginodendron and Heterangium. Phil. Trans. Roy. Soc. London 186B:703-779.

WORSDEL, W. C. 1906. The structure and origin of the $\mathrm{Cy}$ cadaceae. Ann. Bot. 20:129-159.

ZAHUR, M. S. 1959. Comparative study of secondary phloem of 423 species of woody dicotyledons belonging to 85 families. Cornell Univ. Agr. Exp. Sta. Mem. 358:1-160. 